\title{
The Effect of Financial Leasing Threshold in the Financial Development and Economic Growth: Evidence from Albania
}

\author{
Submitted 05/03/21, $1^{\text {st }}$ revision 08/04/21, $2^{\text {nd }}$ revision 02/05/21, accepted 20/05/21
}

Llesh Lleshaj $^{1}$, Dorina Kripa ${ }^{2}$

\begin{abstract}
:
Purpose: The main aim is to analyze the effect of the financial system in the economic growth and if the loan impact is conditioned or not by the financial leasing threshold.

Approach/Methodology/Design: The proceeding data are time series of Albania's macroeconomic indicators, from 2008 to 2020 (quarterly frequency). The dependent variable is Gross Domestic Product, threshold variable is financial leasing, and the independent variables are business and individual loans from the banking system, the rate of private loans to domestic loans, monetary aggregate M2, deposits (with and without term) of the banking system. The statistical approach is based on the generalized method of moments for endogenous and exogenous variables in the threshold model.

Findings: There is a financial leasing threshold level in which financial variables of bank loans and domestic loans are related to economic growth by changing the correlation direction.

Practical Implications: the article demonstrated the empirical impacts that ought to be taken into consideration by the banking sector and financial leasing institutions to make decisions for further incentives in developing financial leasing.

Originality/Value: The research provides empirical results encouraging further investigations on the subject matter.
\end{abstract}

Keywords: Financial leasing, financial system, threshold model, economic growth.

JEL classification: C58, E10, G21, G23.

Paper Type: Research Paper.

${ }^{1}$ Ph.D. in Statistics, lecturer at Department of Finance, Faculty of Economy, University of Tirana, Albania, lleshlleshaj@feut.edu.al;

${ }^{2}$ Prof., Assoc., Head of Department of Finance, Faculty of Economy, University of Tirana, Albania,dorinakripa@feut.edu.al; 


\section{Introduction}

The determination of the finance leasing in Albania is stated by the International Accounting Standards (IAS 17), so that "a finance lease is the lease transfers substantially all the risks and rewards incidental to ownership." According to IAS 17, the leases in the financial statements of lessees-finance leases are at the commencement of the lease term, lessees recognize finance leases as assets and liabilities in their statements of financial position at amounts equal to the fair value of the leased property or, if lower, the present value of the minimum lease payments, each determined at the inception of the lease. The businesses, especially the small and medium enterprises (SME), have the possibility, through the financial leasing institutions, to obtain the financing sources but also modern technological lines, machinery, vehicles or services from consolidated producers or furnishers in the country and abroad, by enabling the increase of their products and services quality. This way become competitive in the internal and foreign markets.

The international leasing industry remains an essential contributor to global economic development and demonstrates innovation and flexibility in the face of regulatory change and economic turbulence. North America, Europe, and Asia account for more than $95 \%$ of world leasing volume. As reported by "WCG Global Leasing Report 2020", the global leasing industry has followed the ninth year of uninterrupted growth. The annual growth of leasing in Albania is on average $12.78 \%$ twice or more significant than the $5.55 \%$ average annual growth of the global leasing industry (for the period 2008 - 2018). However, Albania's financial leasing has demonstrated the instability of the growth rate with annual volatility equal to $24 \%$, while the same indicator for the global industry is more stable with annual volatility equal to $14 \%$.

Both in the world and Albania, leasing financing is a promising financial market for financing SMEs. In the last decade, according to the Institute of official statistics in Albania, about $98-99 \%$ of businesses are SMEs, so financial leasing is a relevant financial opportunity for the development of these enterprises and the whole national economy. Currently, ten non-bank financial institutions are operating in the Albanian market in the field of leasing financing. The earliest institutional establishment dates in the years 2007/8. As seen this subsector is a new leasing financing market in Albania, so it cannot be the primary source of medium-term financing for businesses. According to the Bank of Albania, at the end of 2019, financial leasing activities are oriented to entities that remain business with $82 \%$.

The following section examines the comprehensive literature review on financial leasing as macro factors in the relationship with economic growth and finance leasing as micro factors in the relationship with firm financing. Several main reasons motivate this study to focus on finance leasing: Firstly, this financial source is an excellent financing potential for Albania SMEs. Secondly, financial leasing in Albania is a new financial market. Therefore, there is an immediate need for studies from both parts of finance and banker experts and academics. 
The study's central hypothesis is as follows:

$H_{1}$ : The financial system development will affect the economic growth, and its impact of loans is conditioned by financial leasing threshold.

Testing this hypothesis, we will examine bank lending's effect on Albanian economic growth. The following quarterly data are time series of macroeconomic indicators from 2008 to 2020 . The threshold model will be used to estimate the non-linear effect of bank loans (financial development) on economic growth related to a threshold effect of finance leasing. This model is based on the generalized method of moments (GMM) for endogeneity (threshold variables) and exogenous variables (nonthreshold variables). We highlight that the study does not consider the effect of the Covid-19 pandemic on economic growth.

\section{Literature Review}

\subsection{Overall Review of Financial Leasing}

In the past, finance leasing's main focus was on tax differences from the lessor and lessee positions (Stanton and Wallace, 2004). Years later, finance leasing is primarily financing based on its asset (Burgress, 2002). The asset owner will retain ownership of the asset during the whole period of the lease (Bierman, 2005), and the lessee will have to pay agreed periodic rentals for using the leased asset based on the arrangements that were made on the contract (Contino, 2004). In the Leasing Amongst European SMEs report, worked by Oxford Economics (2015), it is reported that "SMEs lease a wide range of assets, demonstrating that the leasing industry can finance almost all of the different types of assets SMEs need to run their businesses."

Leasing in Europe has been a constant and reliable source of support, positively impacting European SME's performance even during the economic crisis (Leaseurope, 2016; Oxford Economics, 2015). Ljeskovica and Poturak (2014) and Gallardo (1997) listed the following factors that should be taken into consideration when a company can choose leasing or bank credit, the request procedures and approval speed, guarantee of repayment, the interest rate, ownership, the creditworthiness of user, technological development, amortization expenses, tax incentives are available through lease financing, etc. Tax treatment has been a strong incentive in some European countries to decide to lease rather than borrow. Also, for SMEs, leasing provides only a lease down payment and no additional collateral compared to bank borrowing frequently, a lease can be arranged in a matter of days (EBRD, 2011; Noja et al., 2020).

\subsection{Financial Leasing in Micro Effect}

Firms can increase their competitive advantage by increasing their financial leverage potential, as well as maintaining a stable debt ratio level, by conserving the possibility of borrowing from banks or issuing more debt securities in the future because of using 
leasing (Ehrhardt and Brigham, 2017; Mellado and Parte, 2017; Monsen and Yiu, 2004). Furthermore, another factor that influences minimizing leasing costs is avoiding maintenance costs by the lessee of the asset (Yan, 2006; Yeh, Chang, and Lo, 2010). Finance leasing helps firms input advanced technologies, and this gain on the new technology generally gives a more significant 'saving' on marginal costs than the added cost of leasing as opposed to buying (Sharpe and Nguyen 1995; Worthington 1995; Mao and Zaleski, 2011).

\subsection{Financial Leasing in Macro Effect}

Whatever the leasing determinants at the firm level are, overall country and sector characteristics are expected to impact significantly. The variation in leasing penetration rates reflects a common factor, a sector factor, a country factor, and an industry-specific disturbance (Drakos and Goulas, 2008; Korkmaz, 2015). Financial leasing has become increasingly important in recent years for financing SMEs in the global market (Zhang, Ling, and Sun, 2019). Moreover, Haiss and Kichler (2009) concluded that leasing and credit positively contributed to economic growth, and leasing and credit are instead complements than substitutes. According to the Central Bank of Albania author Dushku (2009), financial intermediaries' development has an important role and positive effect on economic growth. This conclusion was based on the time-series data by analyzing variables such as money index M2, deposit rate, domestic credit rate, private credit rate, etc. This literature motivates our study to analyze the impact of financial leasing as a threshold variable in the financial system development, affecting Albania's economic growth.

\section{Research Methodology}

The analysis of this study is based on quarterly frequency of time series data from 2008 to 2020 . The meaning of the variables in the model and their description as well as the source of information is shown in Table 1:

Table 1. Meaning of variables and descriptive statistics

\begin{tabular}{llll}
\hline \hline Abbreviation & Description of the variable & Average & $\begin{array}{l}\text { Std. } \\
\text { Dev. }\end{array}$ \\
\hline \hline $\begin{array}{l}\text { The dependent variable: } \\
\text { GDP** }\end{array}$ & $\begin{array}{l}\text { Gross Domestic Product (in current prices and } \\
\text { measured in million ALL). }\end{array}$ & 345,195 & 47,777 \\
\hline $\begin{array}{l}\text { The threshold variables: } \\
F L^{*}\end{array}$ & $\begin{array}{l}\text { Financial leasing for private sector and individuals } \\
\text { (measured as a percentage of GDP). }\end{array}$ & $0.35 \%$ & $0.23 \%$ \\
$M L^{*}$ & $\begin{array}{l}\text { Medium-term loans for private sector and } \\
\text { individuals (measured as a percentage of GDP). }\end{array}$ & $29.68 \%$ & $3.78 \%$ \\
\hline $\begin{array}{l}\text { Non-threshold variables: } \\
\text { Business and individual loans from the banking }\end{array}$ & $\begin{array}{l}\text { system (measured as a percentage of GDP). } \\
\text { Rate of private loans to total domestic loans (in } \\
\text { percentage). }\end{array}$ & $23.52 \%$ & $1.01 \%$ \\
$R P L^{*}$ & & $8.68 \%$
\end{tabular}




$\begin{array}{lllll}M 2 * & \begin{array}{l}\text { Monetary aggregate M2 (measured as a percentage } \\ \text { of GDP). }\end{array} & 198.82 \% & 11.52 \% \\ D^{*} & \begin{array}{l}\text { Total deposits (with and without term) of the } \\ \text { banking system (measured as a percentage of GDP). }\end{array} & 258.05 \% & 22.62 \% \\ E O^{*} & \begin{array}{l}\text { Economic openness index (the ratio of import }+ \\ \text { export/GDP). In model suggested using in }\end{array} & & \\ & \begin{array}{l}\text { logarithm form (Zhang, et al. 2019). } \\ \hline\end{array}\end{array}$

Source: Author's summary, 2020 and authors' calculation in E-views 11. Source of data * is Bank of Albania, and ** is INSTAT.

To get an efficient model, we must first check the variables' stationarity using ADF Test of Unit Root (Dickey and Fuller, 1979). This test is fundamental to testing the series and return it to a stationary series. To perform this, we have used the Augmented Dickey-Fuller test (ADF). The basic equation of the ADF test linked with the constant and the trend (first-order integral) is:

$$
\Delta X_{t}=\lambda_{0}+\lambda_{1} t+\lambda_{2} X_{t-1}+\sum_{i=1}^{p-1} \lambda_{i} \Delta X_{t-1}+\varepsilon_{t}
$$

The first difference $\Delta X_{t}=X_{t}-X_{t-1}$ in the period $t$, where $\lambda_{0}$ is the constant and $t$ is the trend, with the null hypothesis, H0: $\lambda_{2}=0$ (time series data is non-stationary).

Identifying long-run relationship we will use the trace test for cointegration and its maximum eigenvalue statistic (Johansen and Juselius 1990; Gujarat and Porter, 2009). Let $k>2$ be the number of nonstationary and integral first-order series I(1) included in the model, and $r$ the number of vectors that co integrate, where $r \in[0 ; \mathrm{k}-$ 1], then the cointegration hypothesis is: $r \geq 1$ (there is at least one cointegrating pair). Trace test and Max-Eigen values are lower than the critical values, and p-values are also insignificant, which asserts that Vector Error Correction.

Threshold model. This model is based on Kremer et al. (2013) and Zhang et al. (2019). The model is built on time series threshold model, in which generalized method of moments (GMM) are used to allow for endogeneity:

$$
y_{t}=\beta_{1}^{\prime} z_{t} I\left(q_{t} \leq \gamma\right)+\beta_{2}^{\prime} z_{t} I\left(q_{t}>\gamma\right)+\varepsilon_{t}
$$

where $t$ indicates the time series $(t=1,2, \ldots, T)$ and $y_{t}$ is the dependent variable and $\varepsilon_{t}$ is the error term, which is independently and identically distributed. $I($.$) is the$ indicator function indicating the regime defined by the threshold level $\gamma$ and $z_{t}$ is a $m$ dimensional vector of explanatory regressors which may include lagged values of $y$ and endogenous or exogenous variables. The vector of explanatory variables is partitioned into two subsets: $z_{l t}$ represent the exogenous variables that are uncorrelated with $\varepsilon_{t}$, and $z_{2 t}$ includes the endogenous variables that are correlated with $\varepsilon_{t}$. The estimator of the most appropriate threshold value, $\hat{\gamma}$, is associated with the smallest sum of the squared residuals $(\mathrm{S}(\gamma))$, i.e., $\hat{\gamma}=\operatorname{argmin}_{\gamma} S_{n}(\gamma)$. 
Following Hansen (1999) and Carner and Hansen (2004), the determination of the $95 \%$ confidence interval of the threshold value is as follows:

$$
\Gamma=\{\gamma: L R(\gamma) \leq C(\alpha)\}
$$

where $C(\alpha)$ is the 95 th percentile of the asymptotic distribution of the likelihood ratio statistic $L R(\gamma)$. After determining the threshold value, the slope coefficients can finally be defined by the GMM method. Also, to evaluate the parameters $\beta_{\mathrm{i}}$ of the model the ordinary least squares method will be used (Gujarat and Porter 2009), and also the model will be tested for all the main assumptions of the Gauss-Markov Theorem: (1) the linearity; (2) $\mathrm{E}\left(\varepsilon_{\mathrm{t}}\right)=0$; (3) $\mathrm{V}\left(\varepsilon_{\mathrm{t}}\right)=\mathrm{E}\left(\varepsilon_{\mathrm{t}}^{2}\right)=$ constant; and (4) $\operatorname{Cov}\left(\varepsilon_{\mathrm{i}}\right.$; $\left.\varepsilon_{\mathrm{j}}\right)=0$ and $\operatorname{Cov}\left(\mathrm{x}_{\mathrm{i}} ; \mathrm{x}_{\mathrm{j}}\right)=0$ for each $i \neq j$.

\section{Empirical Analysis}

At first, through the ADF-test, time series were transformed into stationary (Table 2 shows time-series that are first-order stationary, or stationary in level), and then these variables were used for parametric estimating of the threshold model of leasing for the economic growth in Albania:

Table 2. Time Series Stationarity Test (ADF: unite root-test).

\begin{tabular}{lllll}
\hline \multirow{2}{*}{ Variable } & Level & \multicolumn{3}{c}{ First difference } \\
\cline { 2 - 5 } & $t$-stat. & Prob. & t-stat. & Prob. \\
\hline \hline FL & -0.1852 & 0.9334 & -6.5818 & 0.0000 \\
$M L$ & -2.3869 & 0.1506 & -4.8951 & 0.0002 \\
BIL & -3.0083 & 0.0411 & -7.3402 & 0.0000 \\
$R P L$ & -1.1846 & 0.6739 & -6.4092 & 0.0000 \\
$M 2$ & -1.0738 & 0.7183 & -4.6118 & 0.0005 \\
$D$ & -1.6541 & 0.4478 & -6.4213 & 0.0000 \\
$G D P$ & -1.5360 & 0.5072 & -7.7440 & 0.0000 \\
EO & -2.8196 & 0.0635 & -2.8322 & 0.0068 \\
\hline \hline
\end{tabular}

Note: $I(1)$ shows that the series is first-order integral (i.e., it is stationary with first difference, or symbol $\triangle$ ).

Source: Authors' calculation in E-views 11.

According to the empirical analysis for the financial leasing threshold model there are two regimes for the threshold variable "finance leasing", with parameter estimations as in Table 3:

Table 3. Threshold model with threshold variable FL (finance leasing)

\begin{tabular}{lll}
\hline \hline Dependent variable GDP & & \\
\hline \hline Threshold Variables, & Coefficient $(\alpha)$ & Prob. \\
$L F<\gamma$ & 30293.11 & 0.6393 \\
$\Delta \mathrm{BIL}_{\mathrm{t}}$ & -1521454 & $0.0081^{*}$ \\
$\Delta \mathrm{RPL}_{\mathrm{t}}$ & Coefficient $(\beta)$ & Prob. \\
\hline Threshold Variables, & & \\
\hline
\end{tabular}




\begin{tabular}{lll}
\hline$L F \geq \gamma$ & & \\
\hline$\Delta \mathrm{BIL}_{\mathrm{t}}$ & -116861.4 & $0.0053^{*}$ \\
$\Delta \mathrm{RPL}_{\mathrm{t}}$ & 479997.0 & $0.0346^{*}$ \\
\hline Non-Threshold Variables & Coefficient $(\varphi)$ & Prob. \\
\hline Constant & 2714.147 & $0.0000^{*}$ \\
$\Delta \mathrm{M} 2$ & -78615.22 & $0.0002^{*}$ \\
$\Delta \mathrm{D}$ & -3801.899 & 0.7604 \\
$\Delta \mathrm{EO}_{\mathrm{t}}$ & 11189.83 & 0.0715 \\
\hline Adjusted $\mathrm{R}^{2}$ & 0.877411 & \\
F-statistic & 49.05646 & $0.0000^{*}$ \\
\hline \hline
\end{tabular}

Note: $\gamma=0.001648604$ and $*$ ) for statistical significance level, $p<5 \%$.

Source: Authors' calculation in E-views 11.

Based on dynamic threshold model estimation, we apply the following model to perform our estimation:

$$
\begin{aligned}
G D P_{t}= & c+\alpha_{1} \Delta B I L_{t} I\left(F L_{t}<\gamma\right)+\alpha_{2} \Delta R P L_{t} I\left(F L_{t}<\gamma\right)+\beta_{1} \Delta B I L_{t} I\left(F L_{t} \geq \gamma\right)+\beta_{2} \Delta R P L_{t} I\left(F L_{t} \geq \gamma\right)+ \\
& +\varphi_{1} \Delta M 2_{t}+\varphi_{2} \Delta D_{t}+\varphi_{3} \Delta E O_{t}+\varepsilon_{t}
\end{aligned}
$$

Where I am indicator term (when FL $<\gamma$ is 1 and 0 otherwise). Using Bai-Perron critical values with scaled F-test (with the statistical significance level, $p<5 \%$ ), there exists a threshold $\gamma=0.16 \%$ for variable threshold "finance leasing." Consequently, this fact is proof of the central hypothesis that the financial system development will affect economic growth, and its impact on loans is conditioned by the financial leasing threshold. This threshold model has successfully passed all the criteria of creating efficient models according to the Gauss-Markov theorem's main assumptions (Table 4), so the model is statistically helpful to explain the direction and strength correlation of the variables. Also, it has parameters and direction of correlation by macroeconomic theories, as written in the empirical literature.

\begin{tabular}{|c|c|c|c|c|c|}
\hline \multirow{2}{*}{ The test } & \multirow{2}{*}{ Null hypothesis } & \multicolumn{3}{|l|}{ Test result } & \multirow{2}{*}{ Decision } \\
\hline & & Statistic. & & Prob. & \\
\hline $\begin{array}{l}\text { Model function: } \\
\text { Ramsey RESET-test }\end{array}$ & $\begin{array}{l}\mathrm{H}_{0}: \text { "the model function is } \\
\text { appropriate (threshold } \\
\text { model)" }\end{array}$ & $\begin{array}{l}\text { F-statistic } \\
0.6717\end{array}$ & $=$ & 0.5168 & $\begin{array}{l}\mathrm{H}_{0} \text { is not } \\
\text { rejected }\end{array}$ \\
\hline $\begin{array}{l}\text { Multicollinearity: } \\
\text { VIF-test (Variance } \\
\text { Inflation Factors) }\end{array}$ & $\begin{array}{l}\mathrm{H}_{0}: \text { "model has not } \\
\text { multicollinearity }\left\{\operatorname{Cov}\left(\varepsilon_{\mathrm{i}} ;\right.\right. \\
\left.\varepsilon_{\mathrm{j}}\right)=0 \text { and } \operatorname{Cov}\left(\mathrm{x}_{\mathrm{i}} ; \mathrm{x}_{\mathrm{j}}\right)=0 \\
\text { for each } i \neq j\} "\end{array}$ & $\begin{array}{l}\text { Uncentered } \\
\text { VIF }<10\end{array}$ & - & --- & $\begin{array}{l}\mathrm{H}_{0} \text { is not } \\
\text { rejected }\end{array}$ \\
\hline $\begin{array}{l}\text { Autocorrelation: } \\
\text { LM-test } \quad \text { (Breusch- } \\
\text { Godfrey) }\end{array}$ & $\begin{array}{l}\mathrm{H}_{0}: \text { "model has not } \\
\text { autocorrelation }\left\{\operatorname{Cov}\left(\varepsilon_{\mathrm{t}}\right.\right. \\
\left.\left.\varepsilon_{\mathrm{t}-\mathrm{p}}\right)=0 \text { for } \mathrm{p}=1,2,3,4\right\} "\end{array}$ & $\begin{array}{l}\text { Chi-squared } \\
0.0484\end{array}$ & $=$ & 0.9761 & $\begin{array}{l}\mathrm{H}_{0} \text { is not } \\
\text { rejected }\end{array}$ \\
\hline $\begin{array}{l}\text { Heteroskedasticity: } \\
\text { Breusch-Pagan- } \\
\text { Godfrey }\end{array}$ & $\begin{array}{l}\mathrm{H}_{0}: \text { "model has not } \\
\text { heteroskedasticity }\left\{\mathrm{E}\left(\varepsilon_{\mathrm{t}}^{2}\right)\right. \\
=\text { constant }\} "\end{array}$ & $\begin{array}{l}\text { F-statistic } \\
1.0491\end{array}$ & $=$ & 0.4134 & $\begin{array}{l}\mathrm{H}_{0} \text { is not } \\
\text { rejected }\end{array}$ \\
\hline
\end{tabular}

Table 4. Analysis of the residual of the model 


\begin{tabular}{|c|c|c|c|c|c|}
\hline $\begin{array}{l}\text { Normality of the } \\
\text { residual distribution } \\
\varepsilon_{t} \text { Jarque-Bera-test }\end{array}$ & $\begin{array}{l}\mathrm{H}_{0} \text { : "the residual }\left\{\varepsilon_{\mathrm{t}}\right\} \text { of } \\
\text { the model has normality } \\
\text { distribution" }\end{array}$ & $\begin{array}{l}\text { Chi-squared } \\
1.1777\end{array}$ & & 49 & $\begin{array}{l}\mathrm{H}_{0} \text { is not } \\
\text { rejected }\end{array}$ \\
\hline
\end{tabular}

Source: The table summarizes the tests once they are proceeded in EViews 11 by the authors.

\section{Empirical Scientific Discussion}

We emphasize that according to the data 2008-2020 taken in the analysis, the value of finance leasing is on average one hundred times smaller than the value of other forms of financing (loans) in Albania. According to the threshold estimation, we find out a non-linear relation between bank loans and economic growth that is associated with a threshold effect of the financial leasing level, as shown in Table 3:

\section{(1) For threshold variables (financial leasing), if $L F<\gamma=0.16 \%$ on GDP:}

The rate of private loans/domestic loans (RPL) has a negative and statistically significant relationship with GDP. Under the conditions of a competitive and welldiversified market, the RPL variable should have a positive impact on GDP, because lending turns into investments and consumptions in the economy, but in the Albanian economy if leasing $<\gamma$, the opposite position has occurred because of the lack of financial development in the non-bank institutions (leasing). So, financial intermediaries have reduced their activities because the general loan risk is increased and the cost of loans. The banking system is forced to reduce the default risk (explained by policies for controlling the growing level of non-performing loans). It has increased investment in treasury securities, so the loan has shifted to government instruments, which certainly increases GDP, but the variable RPL is a ratio, where the denominator has increased more than the numerator. The outcome of the ratio marks a decrease by explaining the negative correlation with GDP.

The business and individual loans from the banking system (BIL) have a positive and statistically insignificant relationship with GDP. Increasing the lending level in the economy for businesses and individuals has a direct effect on the GDP through increased investment and consumption and an indirect effect by increasing the public budget from taxes on value-added as well as increasing employment, etc. BIL's direct correlation with GDP is expected, but the statistical insignificance is related to low performance (the high level of non-performing loans in critical economic sectors such as the construction, mining industry, etc.). On the other hand, if the leasing $<\gamma$ has had an increase of the banking concentration (according to the Herfindahl-Hirschman Index published by the Bank of Albania), i.e., decreasing the competitiveness (efficiency) of the financial intermediation system.

\section{(2) For threshold variables (financial leasing), if $L F \geq \gamma=0.16 \%$ on GDP:}

The business and individual loans from the banking system (BIL) have a negative and statistically significant relationship with GDP. As shown in the introduction, financial leasing after 2015 has marked a high growth rate, and individuals and businesses have 
preferred to buy assets with leasing due to the low cost of financing and immediate usage of the asset (although ownership is not transferred). This phenomenon has affected by reducing the growth rate of medium and long-term loans from the banking system compared to the GDP growth. The variable BIL is a ratio where the denominator has increased more than the numerator, and the outcome of this ratio marks a decrease by explaining the negative correlation with GDP. From 2015 to 2020 , there is a negative and statistically significant correlation (the scale is -0.89) between BIL and GDP, consequently, the variables have a significant relationship in the model.

The rate of private loans to total domestic loans (RPL) has a positive and statistically significant relationship with GDP. Based on many studies in different countries, leasing development increases competitiveness in the financial system and reduces the cost of financing and the risk from borrowers. Under these conditions, the banking system has had a lower added risk in the new loans by encouraging increasing the value of loans for businesses and individuals while pursuing a liberal risk policy. The variable RPL is a ratio where the numerator has increased more than the denominator, and the outcome of the ratio marks an increase by explaining the positive relationship with GDP.

\section{(3) For non-threshold variables on GDP:}

The monetary aggregate M2 (including money outside banks and time or not time deposits) has a negative and statistically significant correlation with GDP. For a given level of GDP, the growth of the aggregate M2 faces a shift in holding money from considerable value and long-term deposits to liquid assets or cash outside banks. This change negatively affects the banking system's contribution in financing the real economic sectors with loans, and as a result, a phase of reduction of funds in deposits goes out of the banking system in cash form. Throughout data analysis, the aggregate M2 has had a positive trend by indicating a negative correlation with GDP.

Total deposits (with and without term) of the banking system (D) have a negative and statistically insignificant relationship with GDP. During the timeframe taken into analysis, the interest of deposits has decreased significantly (following the introductory rate's downward trend). The depositors' behavior has shifted to shortterm or liquid deposits, causing a discouragement for investment in the deposits. This phenomenon has reduced the power of the banking system to increase lending in the long run (i.e., long-term financing investments in the economy) and the money multiplier. This is why this variable's negative correlation with GDP, on the other hand, economic growth in Albania for the last decade has been in the range $(-3.7 \%$; $5.7 \%$ ) (with many times with economic stagnation), which explains the insignificant statistical correlation.

Economic openness (EO) is measured on a logarithmic scale and has a positive correlation with GDP with a level of significance $\mathrm{p}<10 \%$ (weak statistical significance). The growth of international trade is an indicator of the domestic market 
development and GDP, so it is expected to have a direct relationship. In Albania, for three decades, foreign trade has a deficit balance, so the prices of goods and services are influenced by euros and dollars currency (the foreign exchange rate). In this context, economic openness has negatively affected the economy (especially for the years with lower interest rates) because lower interest rates tend to encourage capital to migrate elsewhere, reducing demand for the currency, and hence lowering its exchange rate, especially for currency in Euro. Therefore, the total result of this variable has a weak statistical relationship with GDP.

\section{Conclusions}

Nowadays, the leasing industry remains an essential contributor to the global economy. Financial leasing in Albania has instability of the growth rate with higher volatility, but still is a promising financial market for financing SMEs, and during years from 2008 to 2020 (with quarterly frequency), the value of finance leasing is on average one hundred times smaller than the value of other forms of bank lending. Applying the statistical approach based on the generalized method of moments for endogenous and exogenous variables in the threshold model, with financial leasing threshold variable, we found out the endogenous variables if the ratio leasing/GDP < $\gamma=0.16 \%$ : The rate of private loans/domestic loans has a negative and statistically significant relationship with GDP because, under the financial leasing threshold, the financial system's efficiency has decreased, and financial risk has increased.

The business and individual loans from the banking system have a positive and statistically insignificant relationship with GDP. This insignificance is caused by banking system concentration and the lack of leasing development, therefore is increased default risk and non-performing loans.

If the leasing/GDP ratio $\geq \gamma=0.16 \%$, the endogenous variables change the direction of the correlation: The rate of private loans/domestic loans has a positive and statistically significant relationship with GDP. Increasing the leasing weight will increase the level of competition in the financial intermediaries' system, and it will decrease default risk and cost of the financial system, which positively affects economic growth.

The business and individual loans from the banking system have a negative and statistically significant relationship with GDP. This inverse relationship is explained by a negative correlation -0.89 and statistically significant starting since 2015 .

Also, the model identifies three exogenous variables:

Monetary aggregate $\mathrm{M} 2$ has a positive and statistically significant relationship with GDP. Total deposits of the banking system have a negative and statistically insignificant relationship with GDP. Economic openness has a positive relationship with GDP (weak statistical significance). 
Taking all statistical analysis and findings of this study into account, the central and local government institutions and financial advisory institutions need to make decisions for further incentives in developing financial alternatives, financial leasing institutions, and enlarging competitiveness of the financial system. According to the financing portfolio and economic sectors, the main limitation of this study derives from the shortcomings of national institutional measurements by financial leasing and advisory institutions. This limitation narrows the concept of the panel data analysis with endogenous and threshold variables in economic growth.

\section{References:}

Bank of Albania. 2008, 2009, ... 2020. Monthly Statistical Report. Retrieved from: https://www.bankofalbania.org/Publications/Periodic/Monthly_Statistical_Repo.

Bank of Albania. 2018. Annual Supervision Report. Retrieved from: https://www.bankofalbania.org/Publications/Periodic/Supervision_Annual_Report/.

Bank of Albania. 2019. Annual Supervision Report. Retrieved from: https://www.bankofalbania.org/Publications/Periodic/Supervision_Annual_Report/.

Berger, A., Udell, G. 2005. A More Complete Conceptual Framework for Financing of

Small \& Medium Enterprises. World Bank Policy Research Working Paper No. 3795.

Bierman, H. 2005. The Lease versus Buy Decision. Englewood Cliffs, NJ: Prentice-Hall.

Boyd, J.H., De Nicolo, G. 2004. The theory of bank risk-taking and competition revisited. The Journal of Finance, 60(3), 1329-1343.

Burgress, D.O. 2002. Buy or lease: the eternal question. Journal of Accountancy, 187(4), 2533.

Caner, M., Hansen, B.E. 2004. Instrumental variable estimation of a threshold model. Econometric Theory, 20(5), 813-843.

Contino, R. 2004. Negotiating Business Equipment Leases. McGraw-Hill Inc.

Dexter, J., Hecimovich, G. 2014. Structuring and Modeling Leasing Investments Tax Perspectives. Deloitte Tax LLP.

Dickey, D., Fuller, W. 1979. Distribution of the estimations for autoregressive time series with a unit root. Journal of American Statistical Association, 74, 423-431.

Drakos, K. Goulas, E. 2008. The relative importance of sector and country factors for leasing penetration rates across European industries. Applied Economics Letters, 15, 1197-1200.

Dushku, E. 2009. Zhvillimi financiar dhe rritja ekonomike: rasti i Shqipërisë. Banka e Shqipërisë.

EBRD (European Bank for Reconstruction and Development). 2011. Special study: Bank's leasing operations (regional).

Ehrhardt, M., Brigham, E. 2017. Financial Management: Theory \& Practice, 15th Edition. Chapter 19.

Elgers, T., Clark, J. 2010. The Lease/Buy Decision: A Simplified Guide to Maximizing Financial and Tax Advantages in the 1980s. New York, NY: The Free Press.

European Commission. 2012. Non-bank financial institutions: Assessment of their impact on the stability of the financial system. Economic Papers 472.

Gallardo, J. 1997. Leasing to Support Small Businesses and Microenterprises. Policy Research Working Paper Series No. 1857. The World Bank. 
Ganguli, T. 2018. Impact of Asset Price Bubbles in Developing Conservative Models for Allowances on Loans and Leases Losses (ALLL) estimate. IFIM's Focus: The International Journal of Management, 13(2), 20-27.

Goldman, E. 2020. Lecturer notes: Data Analysis in Finance. Pace University.

Gujarat, D., Porter, D. 2009. Basic Econometrics, 5th ed. McGraw-Hill.

Haiss, P., Kichler, E. 2009. Leasing and economic growth-evidence for Central and South Eastern Europe. Presentation for European Financial Markets Association.

Hansen, B.E. 1999. Threshold effects in non-dynamic panels: Estimation, testing, and inference. Journal of Econometrics, 93(2), 345-368.

IASB (International Financial Reporting Standards Board). 2016. Effect's analysis: International Financial Reporting Standards, IFRS Foundation, London, UK.

IFC (International Finance Corporation). 2005. Leasing in development: Guidelines for emerging economies. Washington, DC.

Johansen, S., Juselius, K. 1990. Maximum likelihood estimation and inference on cointegration-with applications to the demand for money. Oxford Bulletin of Economics and Statistics, 52(2), 169-210.

Korkmaz, S. 2015. Impact of bank credits on economic growth and inflation. Journal of Applied Finance and Banking, 5(1), 57-69.

Kremer, S., Bick, A., Nautz, D. 2013. Inflation and growth: new evidence from a dynamic panel threshold analysis. Empirical Economics, 44(2), 861-878.

Lease Europe, 2016. Lease Europe's national SME leasing. Roundtable initiative takes off, Press Release, Brussels.

Ljeskovica, A., Poturak, M. 2014. Marketing Factors Affecting Leasing Selection in Bosnia and Herzegovina: Case Study on VB Leasing. European Researcher, 77(6), 1142- 1154

Mao, W., Zaleski, P. 2011. The Effect of Leasing versus Buying on Entry Deterrence. Managerial and Decision Economics, 32, 325-331. DOI: 10.1002/mde.1537.

Mellado, L., Parte, L. 2017. Determinants of corporate lobbying intensity in the lease standard-setting process. Revista de Contabilidad, 20(2), 131-142.

Merton, R.C. 1995. A Functional Perspective of Financial Intermediation. Financial Management, 24(2), 23-41.

Monsen, G., Yiu, J.C. 2004. Single tenant net lease guidelines to achieve maximum financing. Briefings in Real Estate Finance, 4(1), 50-60.

Myers, S., Majluf, N. 2002. Corporate financing and investment decisions when firms have information that investors do not have. Journal of Financial Economics, 7(2), $187-221$.

Noja, G.G., Thalassinos, E., Cristea, M., Grecu, I.M. 2021. The Interplay between Board Characteristics, Financial Performance, and Risk Management Disclosure in the Financial Services Sector: New Empirical Evidence from Europe. J. Risk Financial Management, 14, 79. https://doi.org/10.3390/jrfm14020079.

Noeth, B.J., Sengupta, R. 2011. Is Shadow Banking Really Banking? The Regional Economist, Federal Reserve Bank of St. Louis, 13.

Oxford Economics. 2015. The Use of Leasing Amongst European SMEs: A report prepared for Lease Europe.

Pozsar, Z., Singh, M. 2011. The Nonbank-Bank Nexus and the Shadow Banking System. IMF Working Paper WP/11/289.

Schallheim, J.S. 1994. Lease or Buy? Principles for Sound Decision Making. Harvard Business School Press, Boston.

Sharpe, S.A., Nguyen, H.H. 1995. Capital market imperfections and the incentive to lease. Journal of Financial Economics, 39, 271-94. 
Stanton, R., Wallace, N. 2004. An Empirical Test of a Contingent Claims Lease Valuation Model. Economics, 31(3), 313-315.

Tobias, A., Shin, H.S. 2009. The Shadow Banking System: Implications for Financial Regulation. Banque de France Financial Stability Review, 13, 1-10.

WCG (White Clarke Group). 2020. Global Leasing Report 2020. Retrieved from: https://www.whiteclarkegroup.com/reports/global-leasing-report-2020.

Westley, G. 2003. Equipment Leasing and Lending: A Guide for Microfinance. Washington, D.C., Inter-American Development Bank. Reference No. MSM-122.

Worthington, P. 1995. Investment, cash flow, and sunk costs. Journal of Industrial Economics, 43, 49-61.

Yan, A. 2006. Leasing and debt financing: substitutes or complements? Journal of Financial and Quantitative Analysis, 41(3), 709-731.

Yeh, H.R., Chang, L.W., Lo, H.C. 2010. Optimal threshold values of age and two-phase maintenance policy for leased equipment using age reduction method. Annals of Operations Research, 181, 171-183.

Zhang, Y., Ling, Z., Sun, H. 2019. Does the level of financial leasing matter in the impact of bank lending on economic growth: Evidence from the global market (20062016). Finance Research Letters, Elsevier, 30(C), 352-359. 